\title{
PERAN STRATEGIS PENILAI PBB-P2 BAGI PEMERINTAH DAERAH
}

\author{
Agung Yuniarto \\ Politeknik Keuangan Negara STAN \\ agung.yuniarto@pknstan.ac.id
}

\section{INFORMASI ARTIKEL}

Diterima Pertama

29 Agustus 2019

Dinyatakan Diterima

23 September 2019

KATA KUNCI:

[Peran, Penilai PBB-P2, Pemerintah Daerah].

KLASIFIKASI JEL:

$\mathrm{H} 710$

\section{ABSTRACT:}

According with the Policy on the transfer of tax payments to local governments (Law No. 28/2009 concerning PDRD), the Appraiser of $P B B-P 2$ has an important role for Local Governments to determine the value of land and/ or buildings carried out through a process called the resulting process. About decision NJOP, a decision is made to estimate the value of land and / or buildings as objects of the United Nations. The resulting value will then be distributed into the land or building classification. Seeing such conditions, the UN-P2 assessor discusses the strategic, then how to involve the thinking that must be done by the UN-P2 assessor and its impact on the Regional Government? This paper is intended to find out the strategic role issued by the assessor PBB-P2 in the Local Government in the procurement process. Work outcomes that increase state or regional income from the tax sector. The method used is secondary data analysis (ADS) (Martono, 2011), covering two main processes, namely collecting data and analyzing it. The PBB appraisal P2 is currently the responsibility of local governments, ranging from assignments to those that make professional appraisers incompletely put forward their dear interests in the framework of increasing PAD, also related to the sociological and cultural aspects of the region. Local governments now also have a duty to continue to improve the competency and professionalism of tax valuer.

\section{ABSTRAK:}

Sesuai dengan kebijakan pengalihan pemungutan pajak kepada pemerintah daerah (UU No 28 Tahun 2009 tentang PDRD), SDM Penilai PBB-P2 mempunyai peranan penting bagi pemerintah daerah untuk menentukan besarnya nilai tanah dan/atau bangunan dilakukan melalui suatu proses yang disebut dengan proses penilaian. Dalam kaitan dengan penentuan NJOP, penilaian dilakukan untuk mengestimasi nilai tanah dan/atau bangunan sebagai objek PBB. Nilai yang dihasilkan selanjutnya akan dikonversi ke dalam klasifikasi tanah atau bangunan. Melihat kondisi yang demikian, penilai PBB-P2 sangatlah strategis, lalu bagaimana peran sebenarnya yang harus dilakukan oleh penilai PBB-P2 dan dampaknya bagi Pemerintah Daerah? Tulisan ini bertujuan untuk mengetahui peran strategis yang dimiliki oleh penilai PBB-P2 pada Pemerintah Daerah dalam proses kerjanya. Hasil kerja yang berdampak bagi penerimaan negara atau daerah dari sektor pajak. Metode yang digunakan yaitu analisis data sekunder (ADS) (Martono, 2011), mencakup dua proses pokok, yaitu mengumpulkan data dan menganalisisnya. Penilai PBB P2 saat ini menjadi tanggung jawab pemerintah daerah, mulai dari penugasannya sampai dengan berusaha untuk menjadikan penilai profesional dengan tidak semata-mata mengedepankan kepentingan dearah dalam rangka meningkatkan PAD, tetapi juga mempertimbangkan aspek sosiologis dan kultural daerah. Pemerintah daerah saat ini juga mempunyai tugas untuk terus meningkatkan kompetensi dan profesionalitas penilai pajak. 


\section{PENDAHULUAN}

\subsection{Latar Belakang}

Perpajakan Daerah mengalami reformasi yang ditandai dengan Undang-Undang Nomor 28 Tahun 2009 tentang Pajak Daerah dan Retribusi Daerah. Undang-Undang ini telah mengatur pengalihan pajak pusat menjadi pajak daerah, salah satunya yaitu Pajak Bumi dan Bangunan Perdesaan dan Perkotaan (PBBP2). Setelah PBB-P2 resmi dialihkan kepada pemerintah daerah, maka $100 \%$ hasil penerimaan PBB-P2 dapat menjadi peluang dan tantangan tersendiri bagi pemerintah daerah untuk meningkatkan penerimaan dan kemandirian daerah.

Upaya ini adalah merupakan desentralisasi fiskal dengan pengelolaan penerimaan, dalam hal ini pajak dan retribusi. Penerimaan dari pajak merupakan salah satu aspek penting dalam rangka meningkatkan pendapatan asli daerah (PAD). Penerimaan dari sektor pajak merupakan instrumen pembiayaan operasional dalam rangka pelayanan masyarakat.

Kebijakan ini adalah merupakan salah satu upaya dalam pengembangan otonomi daerah yang dilakukan melalui peningkatan kapasitas kelembagaan pemerintahan daerah, peningkatan kapasitas aparatur pemerintahan daerah, peningkatan kapasitas keuangan pemerintahan daerah, dan penguatan demokrasi lokal. Dengan meningkatkan kekuatan pajak daerah (local taxing power) diharapkan strategi tersebut dapat mewujudkan agar kebijakan tersebut dilakukan melalui sosialisasi dan bantuan teknis untuk peningkatan kepatuhan membayar pajak daerah serta kerjasama administrasi pajak daerah pemerintah provinsi dan pemerintah kabupaten dan kota. Berlakunya undang-undang tersebut menjadikan Pajak Bumi dan Bangunan Perdesaan dan Perkotaan yang disebut PBB-P2 dari Pajak Pusat menjadi Pajak Daerah serta diharapkan mampu menjadi salah satu sumber penerimaan PAD yang penting bagi setiap daerah.

Melalui regulasi ini, diharapkan peran daerah dalam mendukung perekonomian nasional menjadi semakin besar. Di samping itu, kondisi perekonomian dan globalisasi cenderung menuntut adanya peran aktif dari pemerintah daerah untuk lebih banyak menggali potensi daerahnya, serta memainkan peranan yang lebih besar dalam merangsang aktivitas ekonomi daerah. Dengan semakin besarnya kegiatan ekonomi suatu daerah, diharapkan akan dapat meningkatkan penerimaan asli daerah sebagai instrumen penerimaan pembangunan. PAD memiliki peranan penting dalam rangka pembiayaan pembangunan dan pelayanan di daerah. Berdasarkan pada potensi yang dimiliki masing-masing daerah, peningkatan dalam penerimaan PAD ini akan dapat meningkatkan kemampuan keuangan daerah. Pemerintah daerah membutuhkan pajak daerah untuk melaksanakan pembangunan di berbagai sektor. Pembangunan terus berjalan karena pembayaran pajak yang dilakukan masyarakat. Pembangunan dan pengelolaan pajak merupakan tanggung jawab pemerintah daerah terutama berkaitan dengan penyediaan infrastruktur atau prasarana daerah.

Dengan adanya kebijakan pengalihan pemungutan pajak kepada pemerintah daerah maka baik buruknya kinerja dalam pelaksanaan pembangunan sangat bergantung dari bagaimana konsistensi dan implementasi pengelolaan pajak khususnya PBB-P2 yang secara sah menjadi kewenangan pemerintah daerah. Tercapainya target penerimaan Pajak Bumi dan Bangunan Perdesaan dan Perkotaan (PBB-P2) akan ditentukan oleh sejauh mana usaha yang dilakukan pemerintah daerah, dalam hal ini yang berwenang dalam pengalihan PBBP2 bukan lagi Kantor Pelayanan Pajak melainkan Dinas Pendapatan Daerah. Tentunya diharapkan pemerintah daerah dapat memaksimalkan kebijakan ini sebagai upaya pemerintah daerah meningkatkan penerimaan dalam mewujudkan pemerataan pembangunan agar tidak terlalu senjang antara satu daerah dengan daerah lainnya. Konsekuensi pengalihan ini maka kegiatan pendataan, penilaian, penetapan, pengadministrasian, pemungutan/ penagihan, dan pelayanan PBB-P2 akan diselenggarakan oleh kabupaten/kota. Adapun tujuan pengalihan pengelolaan PBB-P2 ke kabupaten/kota adalah untuk memberikan kewenangan yang lebih besar dalam perpajakan dengan memperluas basis pajak daerah dan penetapan tarif pajak.

Salah satu kunci berhasilnya penerimaan PBB adalah terus menerus melakukan penyempurnaan teknis penentuan Nilai Jual Obyek Pajak (NJOP). Penyempurnaan dalam menentukan NJOP perlu terus dilakukan karena NJOP merupakan dasar pengenaan Pajak Bumi dan Bangunan. Apabila penentuan NJOP ini kurang baik dan benar akan berdampak pada ketetapan Pajak Bumi dan Bangunan. Sementara berdasarkan fakta yang ada bahwa sampai dengan saat ini sebagian besar pemerintah daerah masih mengalami kesulitan dalam menetukan NJOP terbukti dengan maraknya aksi penolakan atas NJOP yang ditetapkan berbagai daerah sebagaimana kasus di bawah ini:

- 400 kepala desa melakukan aksi protes di Kabupaten Majalengka meminta pemerintah meninjau ulang nilai Pajak Bumi dan Bangunan (PBB) yang dianggap terlalu tinggi. Kenaikan angka tagihan dibandingkan tahun sebelumnya mencapai 400\%. Kenaikan PBB itu dinilai tidak wajar dan memberatkan masyarakat. Bahkan, tak menutup kemungkinan tunggakan PBB di 
masyarakat akan lebih tinggi dibanding tahun lalu, karena nilai NJOP yang terlalu tinggi atau PBB yang harus dibayar tinggi maka semua Surat Pemberitahuan Pajak Terhutang (SPPT) kini belum diserahkan kepada masyarakat ((Tati Purniawati, www.pikiran-rakyat.com, 3 April 2017).

- Pemerintah Kota Palembang menaikkan tarif pajak bumi dan bangunan (PBB) lebih dari $100 \%$. Peningkatan tarif PBB tersebut akibat dari penyesuaian nilai jual objek pajak (NJOP) berdasarkan zonasi. Bahkan Kementerian Dalam Negeri (Kemendagri) menyorot penyesuaian NJOP yang mengakibatkan kenaikan PBB secara drastis di Kota Palembang, yang menuai penolakan masyarakat (Triajie, DDTCNews, 14 Mei 2019).

- Warga Kota Bekasi mengeluhkan kenaikan pajak bumi dan bangunan (PBB) yang semakin tinggi. Kenaikan PBB di Kota Bekasi bervariasi, mulai dari 15 hingga 400 persen tanpa ada pemberitahuan atau sosialisasi terlebih dahulu kepada masyarakat atau wajib pajak (Mikael Niman, Beritasatu.com, 25 Februari 2019).

- Rencana Pemerintah Kota Bontang untuk menaikkan Nilai Jual Objek Pajak (NJOP) akhirnya benar - benar terlaksana. Secara resmi, kenaikan NJOP mulai berlaku tahun ini. Berdasarkan hasil penelitian, NJOP bisa naik signifikan dengan rata rata kenaikan sekitar tujuh tingkat atau 230 persen (Supriono, www.paradase.id, 5 Juli 2019)

Perubahan NJOP yang membawa implikasi pada aksi masyarakat tentu saja menjadi preseden buruk bagi pemerintah daerah dalam tata kelola pajak daerah terutama PBB-P2. Karena itulah pemerintah daerah harus menyiapkan sumber daya manusia (SDM/pegawai) yang mampu melaksanakan pekerjaan teknis dalam pelaksanaan administrasi PBB-P2. Salah satu pekerjaan teknis yang sangat menetukan dalam pengenaan PBB-P2 adalah pekerjaan penilaian objek PBB-P2. Pekerjaan penilaian objek PBB-P2 akan dapat dilaksanakan dengan baik dan objektif hanya oleh SDM yang memiliki kualifikasi dalam bidang penilaian yang selanjutnya diangkat menjadi penilai. Penilai adalah mereka yang mampu mengestimasi nilai atas suatu properti dengan berpedoman pada teori penilaian serta aturan yang ada. Dalam tulisan ini akan diuraikan peran penilai dalam melaksanakan administrasi PBB-P2 serta kualifikasi minimal yang harus dipenuhi oleh SDM tersebut sehingga nilai yang dihasilkan dapat dipertanggungjawabkan.

SDM Penilai PBB-P2 ini mempunyai peranan penting bagi Pemerintah Daerah untuk menentukan besarnya nilai tanah dan/atau bangunan dilakukan melalui suatu proses yang disebut dengan proses penilaian. Secara umum dapat dinyatakan bahwa penilaian merupakan suatu proses yang dilakukan oleh penilai untuk mengestimasi nilai dari suatu properti. Dalam kaitan dengan penentuan NJOP, penilaian dilakukan untuk mengestimasi nilai tanah dan/atau bangunan sebagai objek PBB. Nilai yang dihasilkan selanjutnya akan dikonversi kedalam klasifikasi tanah atau bangunan. Hasil konversi tersebut akan menjadikan klasifikasi tanah atau bangunan dan dari klasifikasi tersebut akan ditentukan besarnya NJOP per meter persegi tanah atau bangunan. Melihat kondisi yang demikian, penilai PBB-P2 sangatlah strategis, lalu bagaimana peran sebenarnya yang harus dilakukan oleh penilai PBB-P2 dan dampaknya bagi Pemerintah Daerah?

Tulisan ini bertujuan untuk mengetahui peran strategis yang dimiliki oleh penilai PBB-P2 pada pemerintah daerah dalam proses kerjanya. Hasil kerja yang berdampak bagi penerimaan negara atau daerah dari sektor pajak.

\section{KERANGKA TEORI}

\subsection{Pajak Daerah}

Soemitro, (2005) menjelasksan bahwa pajak merupakan iuran rakyat kepada kas negara berdasarkan Undang-Undang (yang dapat dipaksakan) dengan tidak mendapat jasa timbal balik (kontra prestasi), yang langsung dapat ditunjukkan dan yang digunakan untuk pengeluaran umum. Pajak Daerah menurut Undang-Undang Nomor 28 Tahun 2009 adalah iuran wajib yang dilakukan oleh orang pribadi atau badan kepada Daerah, tanpa imbalan langsung yang seimbang, yang dapat dipaksakan berdasarkan peraturan perundang-undangan yang berlaku, yang digunakan untuk membiayai penyelenggaraan Pemerintahan Daerah dan Pembangunan Daerah.

Untuk mengoptimalkan pendapatan melalui pajak daerah maka optimalisasi pemungutan pajak daerah yaitu dapat dilakukan dengan cara Andriani (2001):

1. Pendataan potensi Pajak dalam rangka menghitung potensi pajak daerah, perlu kiranya dianalisis terlebih dahulu data potensi pajak oleh Dinas Instansi terkait, misalnya saja jumlah subjek, objek, masing-masing pajak daerah.

2. Pengawasan pajak dilakukan untuk menentukan apakah wajib pajak sudah betul, sudah wajar dalam membayar pajak, dan untuk menilai apakah pelayanan yang diberikan oleh petugas pajak sudah sesuai dengan SOP yang berlaku.

3. Koordinasi guna lebih mengoptimalkan pendapatan khususnya pada sektor pajak dearah, diperlukan kerja keras dan kesungguhan dalam upaya menggali potensi pajak daerah yang ada. Penyamaan persepsi antara petugas 
pendapatan, pengolah data dan petugas penagihan menjadi sebuah keharusan dalam rangka meningkatkan potensi pajak daerah.

4. Strategi pemungutan Belum semua potensi pajak tergali secara maksimal, dengan keterbatasan sumber daya yang tersedia serta kesadaran wajib pajak terhadap pelaksanaan regulasi peraturan yang berlaku masih rendah, maka instansi terkait dalam hal pemungutan pajak harus berupaya untuk melakukan reformasi baik secara administrasi maupun penyederhanaan prosedur pelayanan, sehingga diharapkan bisa menyadarkan wajib pajak terhadap arti pentingnya pajak dan taat membayar pajak.

\subsection{Kompetensi}

Beban kerja penilai PBB P2 perlu ditunjang dengan dengan kompetensi yang memadai. Kompetensi diartikan sebagai kemampuan untuk menjalankan aktivitas dalam pekerjaan atau fungsi sesuai dengan standar yang diharapkan (Sudarmanto, 2014). Ismail dan Abidin (2010) menjelaskan bahwa kompetensi yang merupakan konsep yang menyentuh pengetahuan dan keterampilan dan berbagai elemen yang penting. Kerangka kerja ini melibatkan empat dimensi kompetensi, yaitu kognitif, fungsional, sosial dan meta. Tiga dimensi kognitif, fungsional dan sosial dan memiliki nilai-nilai universal. Dalam kerangka ini, tingkat pengetahuan dijelaskan oleh kompetensi kognitif, tingkat keterampilan oleh kompetensi fungsional, sementara itu, kompetensi sosial menjelaskan perilaku dan sikap individu pekerja. Kompetensi Meta terkait dengan kemampuan untuk memperoleh kompetensi ini melalui pengetahuan individu itu sendiri.

\section{METODOLOGI PENELITIAN}

Metode analisis data sekunder (ADS) pada prinsipnya menggunakan data sekunder dalam proses penelitiannya (Martono, 2011). ADS itu sendiri merupakan suatu strategi penelitian yang memanfaatkan data kuantiatif ataupun kualitatif yang sudah ada, untuk dianalisis. Analisis data sekunder itu mencakup dua proses pokok, yaitu mengumpulkan data dan menganalisisnya. Martono (2011) menjelaskan lebih mendalam bahwa ada beberapa hal yang menjadi kelebihan analisis data sekunder adalah hemat waktu, tenaga dan biaya, dan juga memungkinkan meneliti gejala sosial secara makro. Proses ini dapat memanfaatkan sumber data yang sudah ada dan kita tinggal memakainya. Kita dapat memanfaatkan majalah, koran, acara TV, buku-buku, syair lagu, cerita film sebagai objek penelitian.

\section{HASIL PENELITIAN}

Pembangunan merupakan proses yang tidak berujung, perbaikan regulasi dan penataan sistem terus diperkuat guna menjadikan pembangunan daerah terus bergeliat untuk perbaikan tata kehidupan masyarakatnya. Proses pembangunan daerah yang dilaksanakan didasarkan pada semangat otonomi daerah telah mendorong pemerintah daerah untuk lebih mengembangkan daerahnya melalui serangkaian tindakan pemanfaatan potensi daerah secara optimal. Dengan diberlakukannya otonomi daerah telah memunculkan perkembangan lingkungan yang strategis baik pada tatanan lokal maupun nasional yang mendorong terjadinya reformasi dan berdampak pada pergeseran paradigma penyelenggaraan pemerintahan dari yang bersifat sentralistik menjadi besifat desentralistik. Salah satu wujud nyata yaitu adanya regulasi pengelolaan PBB-P2 yang awalnya masuk sebagai penerimaan negara, namun untuk beberapa tahun ini sudah bergeser menjadi peneriman daerah setempat.

\subsection{Esensi Undang-Undang 28 Tahun 2009 tentang Pajak Daerah dan Retribusi Daerah}

Undang-Undang (UU) Nomor 28 Tahun 2009 tentang Pajak Daerah dan Retribusi Daerah (PDRD) sebagai pengganti Undang-Undang Nomor 34 Tahun 2000, daerah diberikan kewenangan yang lebih besar dalam mengatur pajak daerah dan retribusi daerah. Artinya saat ini daerah telah diberikan kewenangan untuk memungut pajak (taxing power). Selain PBB-P2, Undang-Undang tersebut juga turut juga mengalihkan Bea Perolehan Hak atas Tanah dan Bangunan (BPHTB) dan menjadi pajak daerah. Pasal 79 Undang-Undang (UU) Nomor 28 Tahun 2009 mengamanatkan NJOP sebagai Dasar Pengenaan Pajak Bumi dan Bangunan Pedesaan dan Perkotaan (PBB-P2) yang besarannya ditetapkan oleh Kepala Daerah setiap tiga tahun, kecuali, untuk objek pajak tertentu yang dapat ditetapkan setiap tahun sesuai perkembangan wilayahnya. Hal mendasar inilah yang setidkanya pelru dipahami oleh pemerintah daerah akibat regulasi tersebut.

Pelimpahan pengelolaan PBB P2 kepada pemerintah daerah akan dilaksanakan selambatlambatnya pada bulan Januari 2014 (pasal 182 ayat (1) Undang-Undang Pajak Daerah dan Retribusi Daerah (PDRD), sedangkan pelimpahan pengelolaan BPHTB selambat-lambatnya pada bulan Januari 2011 (pasal 182 ayat (2) UU PDRD).

PBB-P2 dipungut berdasarkan pada UndangUndang Nomor 28 tahun 2009 tentang Pajak Daerah dan Retribusi Daerah (PDRD). Dalam pasal 81 diatur bahwa "besaran $P B B-P 2$ yang terutang dihitung dengan cara mengalikan tarif sebagai mana dimaksud dalam Pasal 80 ayat (2) dengan dasar pengenaan pajak sebagaimana dimakud dalam Pasal 79 ayat (3) setelah dikurangi Nilai Jual Objek Pajak Tidak Kena Pajak sebagaimana dimaksud dalam Pasal 77 ayat (5)". Dari aturan tersebut perhitungan 
besarnya PBB-P2 terutang dapat diformulasikan sebagai berikut :

PBB P2 terutang $=$ Tarif $\mathrm{x}($ NJOP - NJOPTKP $)$

Dari formulasi tersebut dapat dijelaskan bahwa besarnya PBB-P2 terutang ditentukan oleh besarnya Tarif Pajak, Nilai Jual Objek Pajak (NJOP), dan Nilai Jual Objek Pajak Tidak Kena Pajak (NJOPTKP). Tarif pajak, sebagai mana diatur dalam pasal 80 UndangUndang Pajak Daerah dan Retribusi Daerah (PDRD), ayat (1) diatur bahwa "Tarif Pajak Bumi dan Bangunan Perdesaan dan Perkotaan ditetapkan paling tinggi sebesar 0,3\% (nol koma tiga persen)". Sedangkan ayat (2) mengatur bahwa besarnya tarif PBB-P2 diatur dengan Peraturan Daerah. Dari aturan tersebut dapat dinyatakan bahwa penentuan tarif PBB-P2 tidak lagi merupakan tarif tunggal, artinya Pemerintah Daerah besama-sama dengan DPRD dapat menetapkan beberapa macam tarif, asal tidak melampaui $0,3 \%$ sebagai tarif tertinggi.

Point-point penting dalam Undang-Undang di atas mencerminkan perubahan ataupun titik point yang harus dipetakan oleh pemerintah daerah ketika akan menetapkan NJOP PBB-P2. Kesalahan pemetaan tidak hanya akan berimplikasi pada pendapatan daerah yang meleset tetapi juga dampak sosiologis di wilayahnya.

\subsection{Peran Penilai PBB-P2 dan Pentingnya Kompetensi Penilai}

Peraturan Menteri Keuangan (PMK) Republik Indonesia Nomor 208/PMK.07/2018 Tentang Pedoman Penilaian Pajak Bumi Dan Bangunan Perdesaan Dan Perkotaan menjelaskan bahwa Penilai PBB-P2 adalah Pegawai Negeri Sipil (PNS) di lingkungan Pemerintah Daerah yang ditunjuk oleh Kepala Daerah, diberi tugas, wewenang, tanggung jawab, dan memiliki kemampuan untuk melaksanakan Penilaian PBB-P2. Peraturan Menteri Keuangan tersebut dibuat bertujuan membantu Pemerintah Daerah menetapkan Nilai Jual Objek Pajak (NJOP) yang relevan dan reliable, Pemerintah Pusat menyusun Pedoman Penilaian Bumi dan/ atau Bangunan yang secara detil akan menjabarkan lebih lanjut teknik dan tata cara penilaian sebagaimana diatur dalam Penjelasan Pasal 79 ayat (1) UndangUndang Nomor 28 Tahun 2009. Melalui Pedoman Penilaian ini, Pemerintah Daerah diharapkan dapat menetapkan Peraturan Kepala Daerah tentang Tata Cara Penilaian PBB-P2 serta menerbitkan Keputusan Kepala Daerah tentang Nilai Jual Objek Pajak (NJOP) dengan Nilai yang telah dimutakhirkan. Peran inilah yang harus 'dimainkan' oleh penilai untuk kepentingan bersama antara kepentingan daerah dan masyarakat luas.

Dalam rangka mengeleminir dampak negatif akibat kompetensi penilai yang kurang memadai, maka regulasi mengenai persyaratan penilai pajak dan asisten pajak pun dibuat. PermenPAN nomor 11/2018 mengatur tentang Jabatan Fungsional Penilai Pajak menjelaskan bahwa Pejabat Fungsional Penilai Pajak yang selanjutnya disebut Penilai Pajak adalah Pegawai Negeri Sipil (PNS) yang diberi tugas, tanggung jawab, wewenang dan hak untuk melakukan Penilaian dan/atau Pemetaan yang mempunyai kualifikasi profesional yang pelaksanaan tugas dan fungsinya mensyaratkan penguasaan ilmu pengetahuan, metodologi, dan teknik analisis di bidang Penilaian dan/atau Pemetaan. Adapaun persyaratannya diatur dalam Pasal 13 yaitu berijazah paling rendah Sarjana (S-1)/Diploma IV (D-IV) bidang penilaian, ekonomi, keuangan, teknik, hukum, administrasi, atau bidang lainnya sesuai dengan $\mathrm{k}$

ualifikasi yang ditentukan oleh Instansi Pembina; serta mengikuti dan lulus uji Kompetensi Teknis, Kompetensi Manajerial, dan Kompetensi Sosial Kultural sesuai standar kompetensi yang telah disusun oleh Instansi Pembina. Sementara itu dalam PermenPAN nomor 12/2018 tentang Asisten Penilai Pajak dijelaskan bahwa Pejabat Fungsional Asisten Penilai Pajak yang selanjutnya disebut Asisten Penilai Pajak adalah PNS yang diberi tugas, tanggung jawab, wewenang dan hak untuk melakukan Penilaian dan/atau Pemetaan yang mempunyai kualifikasi teknis yang pelaksanaan tugas dan fungsinya mensyaratkan penguasaan pengetahuan teknis, prosedur kerja, dan teknik analisis di bidang Penilaian dan/atau Pemetaan. Pasal 13 aturan ini mensyaratkan kualifikasinya berijazah paling rendah Diploma III (D-III) bidang penilaian, ekonomi, keuangan, teknik, administrasi, atau bidang lainnya, sesuai dengan kualifikasi yang ditentukan oleh Instansi Pembina; serta mengikuti dan lulus uji Kompetensi Teknis, Kompetensi Manajerial, dan Kompetensi Sosial Kultural sesuai standar kompetensi yang telah disusun oleh Instansi Pembina.

Salah satu pekerjaan teknis yang sangat menetukan dalam pengenaan PBB-P2 adalah pekerjaan penilaian objek PBB-P2. Pekerjaan penilaian objek PBB-P2 akan dapat dilaksanakan dengan baik dan objektif hanya oleh Sumber Daya Manusia yang memiliki kualifikasi dalam bidang penilaian yang selanjutnya diangkat menjadi penilai. Penilai adalah mereka yang mampu mengestimasi nilai atas suatu properti dengan berpedoman pada teori penilaian serta aturan yang ada. Sekali lagi penilai PBB-P2 menjadi salah satu tokoh kunci penentu besaran pajak PBB-P2 itu sendiri.

Secara teknis Peraturan Menteri Keuangan (PMK) Nomor 208/PMK.07/2018 Tentang Pedoman Penilaian Pajak Bumi Dan Bangunan Perdesaan Dan Perkotaan telah mengatur tata kerja yang bisa dianut oleh penilai PBB P2. Peraturan Menteri Keuangan (PMK) ini merunut Pasal 79 ayat (1) dan penjelasan UU No 28 Tahun 2009, penetapan Nilai Jual Objek Pajak (NJOP) dapat dilakukan dengan: 
a. Pendekatan Data Pasar atau Perbandingan Harga (Market Data/Sales Comparison Approach);

Pendekatan data pasar dilakukan dengan cara membandingkan objek pajak yang akan dinilai dengan objek pajak lain yang sejenis yang nilai jualnya sudah diketahui dengan melakukan penyesuaian yang dipandang perlu. Persyaratan utama yang harus dipenuhi dalam penerapan, pendekatan ini adalah tersedianya data jual beli atau harga sewa yang wajar. Pendekatan data pasar terutama diterapkan untuk penentuan NJOP tanah, dan untuk objek tertentu dapat juga dipergunakan untuk penentuan NJOP Bangunan

b. Pendekatan Biaya (Cost Approach);

Pendekatan biaya digunakan untuk penilaian bangunan, yaitu dengan cara memperhitungkan biaya-biaya yang dikeluarkan untuk membuat bangunan baru objek yang dinilai dan dikurangi penyusutan. Perkiraan biaya dilakukan dengan cara menghitung biaya setiap komponen utama bangunan, material dan fasilitas lainnya.

c. Pendekatan Kapitalisasi Pendapatan (Income Approach).

Pendekatan kapitalisasi pendapatan dilakukan dengan cara menghitung atau memproyeksikan seluruh pendapatan sewa/penjualan dalam satu tahun dari objek pajak yang dinilai dikurangi dengan kekosongan, biaya operasi, dan/ atau hak pengusaha. Selanjutnya dikapitalisasikan dengan suatu tingkat kapitalisasi tertentu. Pendekatan ini pada umumnya diterapkan untuk objek-objek komersial, yang dibangun untuk usaha/ menghasilkan pendapatan seperti hotel, apartemen, gedung perkantoran yang disewakan, bandar udara, pelabuhan, tempat rekreasi, dan ain sebagainya. Dalam penentuan Nilai Jual Objek Pajak (NJOP), penilaian berdasarkan pendekatan kapitalisasi pendapatan dipakai juga sebagai alat penguji terhadap nilai yang dihasilkan dengan pendekatan lainnya.

Ada dilema dalam penerapan beberapa pendekatan di atas, bila menggunakan data pasar maka Nilai Jual Objek Pajak (NJOP) tentu saja sangat timpang karena selama ini banyak penetapan Nilai Jual Objek Pajak (NJOP) berbeda dengan harga pasar. Sebagai contoh kasus di Wonosobo bahwa Nilai Jual Objek Pajak (NJOP) yang dipakai sekarang berdasarkan harga pasar dimasyarakat telah mengalami kenaikan, sehingga Pemerintah perlu menyesuaiakan kenaikan harga pasar properti yang terjadi dimasyarakat (bppkad.wonosobokab.go.id). sebagaimana diketahui bersama bahwa Nilai Jual Objek Pajak (NJOP) merupakan nilai jual objek pajak tanah dan bangunan yang merupakan hasil dari proses penilaian yang dilakukan penilai di Direktorat Jenderal Pajak yang tujuan sebenarnya adalah untuk perpajakan, namun dalam prakteknya (NJOP) juga digunakan oleh sebagian kalangan untuk penilai aset lainnya seperti digunakan untuk bagian standar harga tanah ataupun ganti rugi suatu bidang tanah atau properti. Berbicara pendekatan yang menggunakan harga pasar, maka harga pasar tanah memiliki kecenderungan mengalami peningkatan, namun penyesuaian Nilai Jual Objek Pajak (NJOP) tidak sesuai dengan kenaikan harga pasar, dimana nilai harga jual masing-masing daerah (kelurahan/desa) berbeda satu sama lain.

Dapat dibayangkan bila jumlah tenaga penilai dan waktu pelaksanaan tidak sebanding dengan jumlah objek pajak sehingga mengalami kesulitan melakukan penilaian lahan dan bangunan sebagai penentuan NJOP. Karena itulah langkah antisipasi perlu dipikirkan sejak dini, terutama gejolak masyarakat.

Peran yang tidak mudah bagi Pegawai Negeri Sipil yang bertugas sebagai penilai, yang dalam hal ini pemerintah pusat tetap berusaha membantu penilai pemeirntah daerah melalui Peraturan Menteri Keuangan (PMK) Nomor 208/PMK.07/2018 yaitu perihal Pedoman Penilaian Bumi dan Bangunan dalam rangka membantu Pemerintah Daerah menetapkan Nilai Jual Objek Pajak (NJOP). Hal yang mendasar terbentuknya PMK tersebut yaitu sebagian besar pemerintah daerah kesulitan menetapkan NJOP dan masih menggunakan Nilai Jual Objek Pajak (NJOP) yang belum dimutakhirkan.

Substansi dari ketentuan penilaian PBB-P2 dalam Peraturan Menteri Keuangan tersebut tidak berbeda jauh dengan pedoman yang sebelumnya telah diterbitkan oleh Direktorat Jenderal Perimbangan Keuangan (DJPK) Kemenkeu melalui Buku Pedoman Umum Pengelolaan PBB-P2 tahun 2014. Pedoman ini dikeluarkan saat diputuskan adanya pengalihan wewenang pemungutan pajak PBB-P2 dari sebelumnya oleh Direktorat Jenderal Pajak (DJP) kepada pemerintah daerah. Titik pokoknya yaitu Peraturan Menteri Keuangan yang ada saat ini telah merinci lebih detail terkait teknik dan tata cara penilaian, terutama dalam menentukan Zona Nilai Tanah (ZNT) dan Daftar Biaya Komponen Bangunan (DBKB), guna menjadi salah satu pedoman utama bagi penilai yang dimiliki oleh pemerintah daerah.

Aspek teknis lainnya yang menjadi titik krusial bagi penilai yaitu tahapan setelah penilai memperoleh data harga pasar tanah yaitu penilai akan melakukan analisis perbandingan dan penyesuaian. Perbandingan dilakukan terhadap faktor-faktor yang signifikan berpengaruh terhadap nilai tanah. Proses ini yang sekiranya perlu pencermatan khusus bagi penilai, terlebih dalam mengkaji nilai tanah antara lain lokasi dan fisik tanah. Lokasi tanah berkaitan dengan letak tanah dan persekitaran/lingkungan sekitar tanah, sementara fisik tanah berkaitan dengan keluasan, lebar depan, kondisi tanah, dan lainnya yang melekat pada bidang 
tanah masing-masing. Untuk mendapatkan nilai yang mencerminkan harga pasar hendaknya data pembanding diperoleh dari data transaksi yang baru terjadi dan letaknya tidak terlalu jauh dari tanah yang dinilai, proses yang demikian tentu saja menjaid hal yang sulit ketika berbicara wilayah yang makro.

Permasalahan ini tentu saja menjadi salah stau alasan penggunaan metode penilaian masal yang dilakukan oleh pemerintah daerah. Sebagaimana diketahui bahwa untuk menetapkan Nilai Jual Objek Pajak (NJOP) tanah per M2, permasalahan yang dihadapi pemerintah daerah di lapangan adalah banyaknya jumlah objek pajak yang harus dinilai dalam waktu atau tanggal penilaian yang sama serta jumlah penilai yang terbatas. Berdasarkan hasil proses perbandingan dan penyesuaian tersebut akan diperoleh nilai tanah yang dinilai dan nilai tanah itu sendiri diperoleh berdasarkan bobot (persentase tertentu) dari masing-masing data pembanding yang dianalisis. Semua proses tersebut digunakan untuk penyesuaian nilai yang wajar pada kondisi tanggal 1 Januari tahun pajak berjalan.

PBB-P2 merupakan sumber penerimaan yang penting bagi daerah, bahkan tidak jarang angin segar ini menjadikan daerah melakukan penyesuaian NJOP secara maksimal. Alasan daerah tiada lain untuk mendongkrak Penerimaan Asli Daerah sehingga mampu menopang kebutuhan fiskal daerah guna melanjutkan program pembangunan. Karena itulah pedoman penilaian ini penting dalam menyesuaikan basis pajak Nilai Jual Objek Pajak (NJOP) yang elastis dan rasional. Elastis dengan mencoba menyambut aspirasi euforia masuknya PBB-P2 sebagai pajak daerah dan juga mencoba untuk mengedepankan kepentingan masyarakat luas atas besaran Nilai Jual Objek Pajak (NJOP) yang sekiranya tidak memberatkan. Point terakhir berkaitan dengan rasional nya penetapan Nilai Jual Objek Pajak (NJOP) oleh daerah, dengan tidak melakukan kenaikan semena-mena atas kesempatan yang ada seperti saat ini, bahwa Kepala Daerah diberi kesempatan untuk menetapkan besaran Nilai Jual Objek Pajak (NJOP).

Nilai Jual Objek Pajak (NJOP) yang tertuang dalam Surat Pemberitahuan Pajak Terhutang (SPPT) merupakan output dari proses panjang yang dilakukan oleh tim penilai yang dibentuk pemerintah daerah. Proses penentuan besarnya nilai tanah dan/atau bangunan dilakukan melalui suatu proses yang disebut dengan proses penilaian.

Secara umum dapat dinyatakan bahwa penilaian merupakan suatu proses yang dilakukan oleh penilai untuk mengestimasi nilai dari suatu properti. Dalam kaitan dengan penentuan Nilai Jual Objek Pajak (NJOP), penilaian dilakukan untuk mengestimasi nilai tanah dan/atau bangunan sebagai objek PBB. Nilai yang dihasilkan selanjutnya akan dikonversi kedalam klasifikasi tanah atau bangunan. Hasil konversi tersebut akan menjadikan klasifikasi tanah atau bangunan dan dari klasifikasi tersebut akan ditentukan besarnya Nilai Jual Objek Pajak (NJOP) per meter persegi tanah atau bangunan. Tidak mudah bagi penilai melakukan tugas ini, karena itulah pemerintah sejak dini sudah membuat regulasi terkait kompetensi penilai.

Peraturan Menteri Pendayagunaan Aparatur Negara Dan Reformasi Birokrasi Republik Indonesia Nomor 12 Tahun 2018 Tentang Jabatan Fungsional Asisten Penilai Pajak Pasal 17 menjelaskan bahwa PNS yang menduduki Jabatan Fungsional Asisten Penilai Pajak harus memenuhi standar kompetensi sesuai dengan jenjang jabatan. Kompetensi Jabatan Fungsional Asisten Penilai Pajak meliputi: 1). Kompetensi Teknis; 2) Kompetensi Manajerial; dan 3) Kompetensi Sosial-Kultural.

Penilaian akan dapat dilakukan dengan baik dan menghasilkan nilai yang objektif yang ujung-ujungnya akan dapat menghasilkan nilai yang dapat dipercaya dan dipertanggungjawabkan secara hukum dan teori, maka penilaian harus dilakukan oleh penilai yang mampu dan diangkat sebagai penilai oleh pejabat. Untuk mendapatkan penilai yang mampu, dapat dilakukan dengan melatih pegawai/SDM dari masingmasing pemerintah daerah pada institusi yang melaksanakan tugas pokok dan fungsi melakukan pendidikan dan pelatihan. Hal ini sangat penting, mengingat selain harus menguasai pengetahuan (knowledge) tertentu, penilai juga perlu menguasai keahlian (skill), perilaku yang baik sebagai seorang penilai (attitude), karakteristik fisik dan respon konsisten terhadap berbagai siatuasi atau informasi, sikap, nilai dan citra diri seseorang (Self-concept) (Sudarmanto, 2014). Semua komponen kompetensi tersebut setidaknya akan memperkuat posisi penilai ketika bekerja, dengan segala tantangan dan tekanan kerja.

\subsection{Dampak Hasil Kerja Penilai PBB P2}

Bila ditinjau sebelumnya yaitu sebelum PBB-P2 sebagai pajak daerah, besarnya tarif efektif yang berlaku untuk pengenaan PBB sektor Perdesaan dan Perkotaan adalah sebesar $0,1 \%$ dan $0,2 \%$. Tarif efektif $0,1 \%$ dihitung dari tarif sesuai pasal 5 Undang-Undang Nomor 12 tahun 1985 sebagai mana telah diubah dengan Undang-Undang Nomor 12 tahun 1994 tentang Pajak Bumi dan Bangunan (Undang-Undang PBB) sebesar $5 \%$ dikalikan dengan besarnya Nilai Jual Kena Pajak (NJKP) sebesar 20\% yang diatur dalam Peraturan Pemerintah Nomor 25 tahun 2002 tentang Penetapan Besarnya Nilai Jual Kena Pajak untuk Penghitungan PBB.

Sedangkan besarnya tarif efektif sebesar 0,2\% dihitung dari besarnya tarif sesuai pasal 5 UU PBB sebesar 0,5\% dikalikan dengan Nilai Jual Kena Pajak (NJKP) sebesar 40\%. Nilai Jual Kena Pajak (NJKP) sebesar $20 \%$ dikenakan untuk objek pajak sektor Perdesaan dan Perkotaan yang memiliki NJOP kurang dari Rp1.000.000.000 (satu miliar rupiah). Sedangkan 
NJKP sebesar $40 \%$ dikenakan atas objek pajak sektor Perkebunan, Perhutanan, dan Pertambangan, serta sektor Perdesaan dan Perkotaan dengan NJOP Rp1.000.000.000 atau lebih. Sehingga dapat disimpulkan bahwa tarif efektif $0,1 \%$ diberlakukan untuk objek pajak sektor perdesaan dan perkotaan yang mempunyai Nilai Jual Objek Pajak (NJOP) dibawah Rp1.000.000.000 dan tarif efektif 0,2\% diberlakukan untuk objek pajak sektor perdesaan dan perkotaan dengan Nilai Jual Objek Pajak (NJOP) Rp1.000.000.000 atau lebih (Sukada, 2014)

Pada tahap awal pengelolaan PBB-P2 oleh daerah-daerah maka data nama subjek, obyek, Nomer Objek Pajak (NOP) dan Nilai Jual Objek Pajak (NJOP)-nya yang dipakai masih merupakan warisan dari Direktorat Jenderal Pajak (DJP), sedangkan dalam pasal 79 UU No. 28 Tahun 2009 bahwa besarnya NJOP sebagai dasar pengenaan PBB Perdesaan Perkotaan ditetapkan setiap 3 (tiga) tahun, kecuali untuk obyek pajak tertentu dapat ditetapkan setiap tahun sesuai dengan perkembangan wilayahnya. Pada pasal selanjutnya Pasal 80 (1) Tarif Pajak Bumi dan Bangunan Perdesaan dan Perkotaan ditetapkan paling tinggi sebesar $0,3 \%$ (nol koma tiga persen). (2) Tarif Pajak Bumi dan Bangunan Perdesaan dan Perkotaan ditetapkan dengan Peraturan Daerah.

Paramater inilah yang menjadi acuan pemerintah daerah dalam mengestimasi besaran penyesuaian kenaikan tarif pajak yang akan diberlakukan. Semua proses tersebut tentu saja menjadi pekerjaan rumah bagi penilai yang secara teknis harus mampu menelaah data yang ada, yang hasilnya akan dirasakan langsung oleh pemerintah daerah melalui penetapan NJOP.

Sebagaimana halnya kebijakan publik lainnya, Undang-Undang Nomor 28 tahun 2009 tentang Pajak Daerah dan Retribusi Daerah (PDRD) mempunyai kekuatan memaksa bagi implementor yang menjadi sasarannya, maka pemerintah daerah mau tidak mau, suka tidak suka harus melaksanakan amanat undang undang tersebut. Implementasi kebijakan yang juga mengedepankan kepentingan sosial sehingga perlu juga melihat dan mendengar aspirasi masyarakat luas sebagaimana yang dijelaskan pada bagian awal seperti kebijakan tarif Nilai Jual Objek Pajak (NJOP) agar tidak menimbulkan gejolak masyarakat dan berusaha untuk menyusun akurasi data objek dan subjek pajak dalam Surat Pemberitahuan Pajak terhutang (SPPT) PBB.

Isu pokok pengembangan sumber daya manusia ini bisa dilihat dari proses peningkatan kualitas melalui pendidikan dan pelatihan dimana pemilihan jenis dan tipe pelatihan pengembangan Sumber Daya Manusia yang dinilai cocok dan sesuai dengan kebutuhan yang selama ini menjadi fokus perhatian pemerintah. Disarankan dengan memilih pelatihan yang tepat, dapat merealisasikan tujuan secara efektif dan efisien. Program pendidikan dan pelatihan atau biasanya disebut program diklat merupakan pengembangan sumber daya manusia (Agustina, 2017).

Sebagaimana diketahui bahwa PBB yang dikelola oleh pemerintah pusat terbagi atas 5 (lima) sektor yaitu Sektor Perdesaan, Perkotaan, Perkebunan, Perhutanan/Kehutanan, dan Pertambangan. Namun dari ke 5 sektor tersebut, berdasarkan UndangUndang PDRD, yang dilimpahkan pengelolaannya kepada pemerintah daerah hanya PBB sektor Perdesaan dan Perkotaan saja (disingkat PBB-P2) dan Bea Perolehan Hak atas Tanah dan Bangunan (BPHTB). Berdasarkan analisis penulis ada beberapa hal yang menjadikan PBB sektor Perdesaan dan Perkotaan saja yang dilimpahkan pengelolaannya kepada pemerintah daerah yaitu (Darwin, 2011):

1. Objek PBB-P2 dan Bea Perolehan Hak atas Tanah dan Bangunan (BPHTB) tersebut lokasinya berada di suatu daerah kabupaten/kota, dan aparat pemerintah daerah jelas lebih mengetahui dan lebih memahami karakteristik dari objek dan subjeknya sehingga kecil kemungkinan wajib pajak dapat menghindar dari kewajiban perpajakannya;

2. Lokasi objek PBB sektor Perkebunan, Perhutanan, dan Pertambangan dapat bersifat lintas batas kabupaten dalam arti objek tersebut kemungkinan besar berada di dalam lebih dari satu kabupaten sehingga perlu koordinasi yang lebih intensif dalam menentukan Nilai Jual Objek Pajak (NJOP) perbatasan antara kabupaten yang bersangkutan. Koordinasi bisa tidak berjalan efektif apabila timbul sentiment kedaerahan, sehingga dapat menimbulkkan ketidakharmonisan penentuan Nilai Jual Objek Pajak (NJOP) daerah yang berbatasan;

3. Objek PBB-P2 terdiri dari berjuta-juta objek yang tersebar diseluruh wilayah Republik Indonesia dengan berbagai permasalahan yang cukup menyita perhatian pengelola PBB-P2 tersebut, dengan kata lain pemerintah pusat ingin lebih berkonsentrasi dalam pemenuhan target penerimaan pajak pusat tanpa dibebani hal-hal yang mungkin sepele yang ditimbulkan oleh PBB P2.

Undang-Undang Nomor 28 tahun 2009 tentang Pajak Daerah dan Retribusi Daerah (PDRD) terus disambut gembira mulai dari pemberlakuannya hingga saat ini, setidaknya pemerintah daerah mendapatkan income tambahan yang utuh, bilamana sebelumnya hanya berupa bagi hasil dari pemerintah pusat atas PBB P2 daerahnya.

Namun demikian berlakunya Undang-Undang ini tidak hanya membuat manis daerah saja, tetapi juga melahirkan beberapa masalah yang dirasakan daerah. Tentu saja ada sisi positif dan sisi negatif dari lahirnya Undang-Undang Pajak Daerah dan Retribusi Daerah (PDRD) (Darwin, 2011). 
Sisi positif diantaranya pertama, akurasi data objek dan subjek PBB-P2, dapat lebih ditingkatkan karena aparat pemerintah daerah lebih menguasai wilayahnya apabila dibandingkan dengan aparat pemerintah pusat sehingga dapat meminimalisir pengajuan keberatan dari para wajib pajak PBB-P2; kedua daerah memiliki kemampuan meningkatkan potensi PBB-P2 dan Bea Perolehan Hak atas Tanah dan Bangunan (BPHTB) sepanjang penentuan Nilai Jual Objek Pajak (NJOP) selama ini oleh pemerintah pusat dinilai masih dibawah nilai pasar objek yang bersangkutan (optimalisasi NJOP); dan ketiga pemberdayaan local taxing power, yaitu kewenangan penuh daerah dalam penentuan tarif dan pengelolaan administrasi pemungutan untuk mewujudkan transparansi dan akuntabilitas.

Sisi negatif yang muncul antara lain, pertama peningkatan Nilai Jual Objek Pajak (NJOP) yang sama dengan nilai pasar dapat mengakibatkan naiknya ketetapan PBB yang dapat menimbulkan gejolak masyarakat; kedua, penggunaan tarif maksimum guna meningkatkan potensi PBB-P2 apabila tidak hatihati dan dikaji secara mendalam dapat menimbulkan gejolak masyarakat karena penggunaan tarif maksimum dapat menaikkan PBB-P2 sebesar tiga kali lipat; ketiga, kesenjangan penerimaan PBB-P2 antar daerah makin menonjol karena disparitas potensi penerimaan pajak daerah lainnya.

Daerah yang memiliki potensi penerimaan pajak daerah lainnya atau mengandalkan bagi hasil lain dari pemerintah pusat, cenderung mengabaikan pemungutan PBB P2 (karena sulit dan kompleks bahkan tidak dipungut) dan sebaliknya daerah yang semata-mata mengandalkan penerimaan PBB-P2 kemungkinan akan menerapkan tarif yang maksimal guna menggenjot penerimaannya; dan keempat pendaerahan PBB-P2 dan Bea Perolehan Hak atas Tanah dan Bangunan (BPHTB) dapat mengakibatkan beragamnya kebijakan antara satu daerah dengan daerah lainnya, misalnya perbedaan tarif, Nilai Jual Objek Pajak Tidak Kena Pajak (NJOPTKP), dan Nilai Perolehan Objek Pajak Tidak Kena Pajak (NPOPTKP). Perbedaan tersebut dapat mengakibatkan ketidakadilan baik bagi masyarakat wajib pajak, pelaku bisnis, maupun masyarakat pada umumnya.

\section{KESIMPULAN DAN SARAN}

Penilai PBB-P2 saat ini menjadi tanggung jawab pemerintah daerah, mulai dari penugasannya sampai dengan berusaha untuk menjadikan penilai profesional bekerja dengan tidak semata-mata mengedepankan kepentingan daerah semata dalam rangka meningkatkan $P A D$, tetapi secara luas juga mempertimbangkan aspek sosialogis dan kultural daerah.

Peran penilai untuk pemerintah daerah adalah menentukan nilai jual objek pajak (NJOP) yang lebih relevan dan reliable sesuai dengan pedoman penilaian pajak bumi dan bangunan seperti tertuang dalam Peraturan Menteri Keuangan (PMK) Nomor 208/PMK.07/2018.

Selanjutnya dengan adanya penilai pemerintah daerah tidak perlu menggunakan jasa penilai publik atau bekerja sama dengan Kemenkeu untuk menentukan Nilai Jual Objek Pajak atau bahkan meringankan beban kepala daerah dalam membuat keputusan tentang NJOP. Bahkan profesi penilai didaerah selain penilai pajak berperan dalam menaksir nilai barang pemerintah yang bisa dijadikan dasar pengenaan pajak atau pengambilan keputusan terkait pembangunan infrastruktur. Kemudian, pengambilan keputusan di bidang perbankan, pasar modal, penerbitan sukuk atau Surat Berharga Syariah Negara.

Setelah mempunyai penilai pajak, pemerintah daerah juga mempunyai tugas untuk terus meningkatkan kompetensi dan profesionalitas penilai pajak sebagaimana diatur dalam Peraturan Menteri Pendayagunaan Aparatur Negara Dan Reformasi Birokrasi Republik Indonesia Nomor 12 Tahun 2018 Pasal 36 bahwasannya untuk meningkatkan kompetensi dan profesionalisme, Penilai Pajak diikutsertakan dalam pelatihan, disesuaikan dengan hasil analisis kebutuhan pelatihan dan/atau pertimbangan dari Tim Penilai. Pelatihan yang diberikan kepada Penilai PBB Pemerintah Daerah antara lain dalam bentuk pelatihan fungsional dan pelatihan teknis.

Dampak nyata adanya penilai pajak daerah adalah pekerjaan dalam menentukan Nilai Jual objek Pajak lebih rasional dan efektif, dan menjadikan pendapatan negara/daerah dari sektor PBB-P2 akan meningkat, dan mendatangkan pendapatan asli daerah, karena proses perhitungan Nilai Jual Objek Pajak didasarkan prosedur penilaian Selain itu pengajuan keberatan yang dilakukan oleh masyarakat juga bisa menurun karena penetapan Nilai Jual Objek Pajak bisa dilakukan $70 \%$ dari hasil penilaian Assesment Ratio.

\section{IMPLIKASI DAN KETERBATASAN}

Data peningkatan ataupun perubahan NJOP suatu daerah sangatlah minim, sehingga kesulitan dalam mengeksplorasi narasi untuk menemukan kesimpulan yang lebih holistik. Karena itulah perlu adanya fokus pada kajian suatu daerah yang didukung dengan data memadai.

\section{DAFTAR PUSTAKA (REFERENCES)}

Agustina Rahmawati (2017). Efektivitas Program Penyelenggaraan Diklat di Badan Pengembangan Sumber Daya Manusia Daerah 
Provinsi Jawa Tengah , Jurnal Ilmiah Manajemen Publik dan Kebijakan Sosial - Vol. 1 No. 2,hal: 104-121.

Andriani (2001). Bunga Rampai Pajak dan Retribusi Daerah, Yogyakarta: Amus dan Citra Pustaka.

bppkad.wonosobokab.go.id. Penyesuaian NJOP PBB Kabupaten Wonosobo. diakses 27 Agustus 2019

Darwin (2011). Pendaerahan PBB, BPPK Kementerian Keuangan, Senin, 21 Maret 2011 14:38, bppk.kemenkeu.go.id

Ismail, Rahmah dan Syahida Zainal Abidin (2010). Impact of workers' competence on their performance in the Malaysian private service sector, Business and Economic Horizons Volume 2 Issue 2 July hal: 25-36.

Martono, Nanang. (2011). Metode Penelitian Kuantitatif: Analisis Isi dan Analisis Data Sekunder. Jakarta: RajaGrafindo Persada.

Mikael Niman, Kenaikan PBB Hingga 400\%, Warga Kota Bekasi Mengeluh, Beritasatu.com, 25 Februari 2019, diakses 26 Agustus 2019.

Peraturan Menteri Keuangan Republik Indonesia Nomor 208/PMK.07/2018 Tentang Pedoman Penilaian Pajak Bumi Dan Bangunan Perdesaan Dan Perkotaan.

Peraturan Menteri Pendayagunaan Aparatur Negara Dan Reformasi Birokrasi Republik Indonesia Nomor 11 Tahun 2018 Tentang Jabatan Fungsional Penilai Pajak

Peraturan Menteri Pendayagunaan Aparatur Negara Dan Reformasi Birokrasi Republik Indonesia Nomor 12 Tahun 2018 Tentang Jabatan Fungsional Asisten Penilai Pajak

Rinto Ariwibowo (2011). Penilai? Mengapa dibutuhkan?, www.kompasiana.com tanggal 22 April 2011

Sofyandi, Herman. (2008). Manajemen Sumber Daya Manusia. Yogyakarta: Graha Ilmu.

Soemitro (2005). Dasar-Dasar Hukum Pajak dan Pajak Pendapatan, Bandung: Eresco.

Soeprihanto, Jhon. (2001). Penilaian Kinerja dan Pengembangan Karyawan, Yogyakrta: BPFE.

Sudarmanto (2014). Kinerja dan Pengembagan Kompetensi SDM, Teori, Dimensi Pengukuran dan Implementasi dalam Organisasi, Yogyakarta: Pustaka Pelajar.

Supriono, Tahun Ini, NJOP di Bontang Naik 230 Persen, www.paradase.id, 5 Juli 2019, diakses 26 Agustus 2019
Tati Purniawati, www.pikiran-rakyat.com, Tagihan PBB Melonjak Hingga 400\%, Kepala Desa Protes, 3 April 2017, diakses 26 Agustus 2019.

Triajie Wahyu El Haq, PBB Naik 100\%, Ini Penjelasan BPPD, DDTCNews, 14 Mei 2019, diakses 26 Agustus 2019.

Undang-Undang No 28 Tahun 2009 tentang Pajak Daerah dan Retribusi Daerah.

Wayan I Sukada (2014), Pengelolaan PBB P2 : Kenapa Perlu Penilai ?, BPPK Kementerian Keuangan, Dibuat: Senin, 12 Mei 2014 15:40, bppk.kemenkeu.go.id.

2015, Bagaimana Menetapkan NJOP Tanah Secara Wajar?, BPPK Kementerian Keuangan, Selasa, 14 April 2015 08:12, bppk.kemenkeu.go.id 